\title{
布基材フェノール樹脂積層材料を用いた 歯車における歯の曲げ疲労強度の算定法*
}

\author{
廣 垣 俊 樹*1, 青 山栄一*1, 片 山傳 生*1 \\ 杉 村 和 哉*2, 岩 崎 伸 哉*3, 矢 倉 吉 典*3
}

\section{The Method of Tooth Bending Strength Calculation for Gears Made of Phenolic Resin Reinforced by Cotton Woven Cloth}

\author{
Toshiki HIROGAKI*4, Eiichi AOYAMA, Tsutao KATAYAMA, \\ Kazuya SUGIMURA, Shinya IWASAKI and Yoshinori YAGURA \\ ${ }^{* 4}$ Department of Mechanical Engineering, Doshisha University,
1-3 Miyakodani, Tatara, Kyotanabe shi, Kyoto, 610 0321 Japan
}

\begin{abstract}
In this research, three steps were taken to reach the conclusion. At first, the influence of the anisotropy of the FRP material, difference of module and gear materials on the strength of tooth root was examined. And, the effect of fracture characteristics and fiber orientation of the gear made of laminated material on the strength is examined by the experiment. Second, until now, this research examines the method of making bending strength equation for isotropic materials such as the metal adjust to FRP gear. Finally, when the gear is used actually, the life of FRP gear is required. The fatigue test is performed in order to understand the life of FRP gear. In conclusion, this research is to establish the way of constructing a design technique for calculating fatigue strength on FRP gears. In this paper the process of calculating fatigue strength is shown.
\end{abstract}

Key Words: FRP, Gear, Fatigue strength, Anisotropy, Plain Woven Cloth, Design System

\section{1. 料}

プラスチック歯車を使用する利点として, 軽量, トライボロジー特性, 低騒音, 組み付け誤差による影 響の低減などが挙げられるいで，そこで，プラスチッ ク歯車の利点を生かし, かつ強度, 剛性の問題を改善 するために樹脂に主に短纎維を充填することにより強 度を向上させた FRP 歯車が様々な分野において適用 されている.

短繊維を用いた射出成形 FRP 歯車に関する研究に ついは，塚本らによってポリアセタールやポリカー ボネートに繊維を充填した歯車の実用性が検討され， その有益性が示されている(1)的。文た摩擦摩耗特性の 運転による変化との関係においても歯車精度, 摩耗量, 歯形形状に着目することにより優位性を持った FRP 歯車の開発が行われている(゙. しかしながら，射出成 形法ではなくホブ切りを前提とした直交積層材料を

* 原稿受付 2003 年 12 月 22 日

*1 正員, 同志社大学工学部( 610-0321 京田辺市多々羅都众 1-3).

*2 (株)イシダ (- 520-3026 栗東市下鈎 959-1).

*3 同志社大学大学院.

E-mail : thirogak@mail.doshisha.ac.jp
FRP 歯車に応用した研究は未だに非常に少ないそ のため, 当該材料を FRP 歯車に応用する場合には明 確な設計基準がないので金属菌車の設計手法を基に数 少ないプラスチック菌車の実験データと経験から歯車 設計を行うしかないのが現状である.

一方 FRP 歯車の応用は，今後条件の厳しい動力伝 達用として期待されるところが大きい，回転伝達のみ を行う場合に比べ, 動力伝達では駆動時に歯に㣫揧荷 重がかかることを考虑して，耐㣫染性の良い材料を選 ぶ必要がある. そのため, 材料内の繊維は短繊稚より も繊維の強化効率の高い直交積層材料 (FRP 積層材 料）を用いる必要が高くなるものと考えられる.

そこで，本研究では直交積層材料を用いた動力伝 達用 FRP 歯車の設計システムを構築する事を目的と した.

動力伝達用 FRP 歯車の強度設計を行う場合, 最も 基本的な評価指標として歯の曲け強さがある. 設計を 行う際には，歯元の繰り返し曲げ疲労による折損を防 止するために，歯元に生じる応力を許容応力以下に設 定寸る必要がある®。しかしながら当該菌車の実際の 歯に疲労訊験を行った報告は無い上うである.そこで 
本報では，特に疲労限も考虑した歯の曲け強度に着目 した.

また本報では機械強度，加工性，耐衝慗性のよい 布基材フェノール樹脂積層材料を用いて FRP 歯車を 製作し，今後利用がより增大寸ると考えられる動力伝 達を目指した FRP 歯車を製作する際の一般的な設計 の指標を検郡する．すなわち，FRP 積層材料を用い た歯車の持つ破壊特性や䋐維配向が歯元の強度に及ぼ 寸影響を調べるために試験片の引張強度や曲け強度と いった基磷的なデータを実験より算出し, 訊験片の破 壊と実歯車での曲け破壊挙動を比較して考察を行った。 また，この材料を用いた場合の破壊形態の特徵なども 明らかにした，さらに，金属などの等方性材料に用い られていた曲け強度式の FRP 歯車への適用を検討し た. さらに歯車を使用する場合に必要となる歯車の疲 労寿命を知るために実際に製作した菌車の歯面に繰り 返し荷重をかける疲労試験を行い，試験片より求めた 材料特性を考虑して疲労強度を算出寸る設計手法の一 指針を示した。

\section{2 実装是および方法}

21 実昖対象齿車 FRP歯車に使用した布基材フェ ノール樹脂積層材料はフェノール樹脂を綿布に含浸さ せて積層した直交異方性を持つ材料である．表 1 にそ の構成を示寸。ここで，本実験で用いた歯車は表 2 に 示す 7 種類の標準平歯車である. まず積層構成を [090]s とした布基材フェノール樹脂積層材料を用いた 5 種類の平歯車 (以後, 標準布強化歯車 $=$ Standard gear と称す）を製作した。 また比較のため同材料で [01+30-30]s と積層した積層材料からと紙基材フェノー 儿樹脂積層材料（等方性材料）からも，平歯車（以後 それぞれ改良布強化歯車=Improved gear，紙強化歯 車=Paper gear と称す）をそれぞれ 1 種類ずつ製作し た.

本研究で菌車に布基材フェノール樹脂積層材料を 用いた利点として，フェノール樹脂のプリプレグは成 形作業環境がよく歯切り前素材の成形能率が上がる, 繊維量のコントロールが容易, 製品の仕上がりが美し いなどの点が举げられる '11'。また強化纎維に綿布を 使用した理由としては材料としての機械強度が高い， 機械加工性，而揰華性が良い，また積層材を歯車に用 いる場合には歯をホブ切りする必要があるが，その時 の機械加工性が良いなどの点が挙げられる.また本材 料は電気絶縁体として広く実用されており入手が容易 で安価でもあるため，今後のホブ切りを前提とした歯 車素材として有望と考えられる.
Table1 Material property

\begin{tabular}{|c|c|c|c|}
\hline \multicolumn{2}{|l|}{ Meterial } & \begin{tabular}{c|l} 
Phenols & Cresol \\
Alkyphend \\
Formalin
\end{tabular} & $\frac{25 \%}{25 \%}$ \\
\hline Reinforced Fiber & & Cotton & \\
\hline Weave Type & & Plain Weavo & \\
\hline Thickness of Cotton Yam & mm & 20 & \\
\hline Thiokness of Ply & $\mathrm{mm}$ & 0.25 & \\
\hline Fiber Concentration & 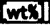 & 50 & \\
\hline
\end{tabular}

Table2 Dimension of gears

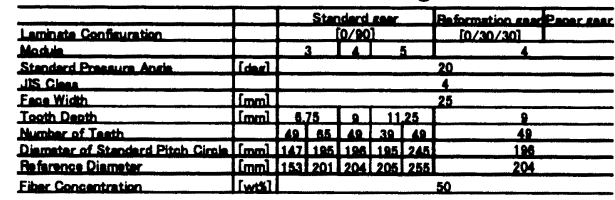

\section{2 実解方法}

221 引張試布基材フェノール樹脂積層材の 基本的な特性を知るために使用した材料の引張圾験を 行った. 本実験では積層構成[090]s の材料において引 張方向に対して纎維の方向が $0^{\circ}, 15^{\circ}, 30^{\circ}, 45^{\circ}$ の 4 種類の試験片を製作し引張試験を行った．また積 層構成を[0 $1+30-30] \mathrm{s}$ とした積層材料においても同様の 試験を行った. この場合, 表面のプリプレグの䋊維方 向が引張り方向に対し $0^{\circ}$ と $15^{\circ}$ の 2 種類の材料にお いて試験を行った。 なお，本試験で使用した試験片の 寸法は長さ : 幅 : 厚さ $=100: 20: 5[\mathrm{~mm}]$ である。

222 引張破㙹挙功の貺察 FRP 積層材料を用い た歯車の持つ破壊特性や䋊維配向が歯元の強度に及ぼ す影響を調べるために，まず単純な形状である圾験片 の引張破壊を観察することにより，基本的な破壊特性 と繊維配向による影響を明らかにする必要がある. そ こで 22.1 で行った引張圾験後の試験片の写真撮影を し，観察と考察を行った.

2233 点曲け試觜車の歯先には曲げ荷重がか かるので, 材料自体の曲け許容応力を知っておく必要 がある，そこで，本実験では菌車に負荷がかかる状態 を考え, 積層方向に対して垂直に荷重がかかるように 試験片を製作した. 3 点曲け試験の実験方法としては, FRP の曲け試験として規定されている JS K $7055 に$ 従って，実験を行ったの. なお，本試験で使用した試 験片の寸法は引張り試験と同様であり, 試験機の標点 間距離は $90[\mathrm{~mm}]$ とした。

224 掼せん断試 歯車の歯は stub 形状である ため，せん断の影響も無視できない，そこで，各試験 片において横せん断試験を行った. 荷重方向に関して は, 3 点曲け試験と同様に, 積層方向に対して垂直に 負荷する，なお，本試験で使用した試験片の寸法は引 
張り試験と同様であり, 試験機のスパンは $25[\mathrm{~mm}]$ と した.

2.2 .5 歯車の曲け破壊試験 歯車における強度の 評価，およひ設計基準の設定を行う場合，歯にどの程 度の負荷をかけると破損寸るかという基礎的デー夕は 非常に重要なものとなる ${ }^{(10)}$. そこで, 歯車を固定し, 先端部を丸めた加圧棒をインストロン試験機に取り付 け，歯先に歯面と垂直な方向となるように線荷重〔負 荷速度 : $5(\mathrm{~mm} / \mathrm{min})$ ] をかけ, 破損時までの最大負 荷の測定を行った.

今回実験に用いた FRP 歯車の場合, 直交異方性を 持つ積層材料を歯車材料として用いているため各歯に より繊維の配向角度が異なる. そのため, 各モジュー ルにおいて繊維配向が $\theta=0^{\circ}$ となる歯を基準とし, 各歯の位置を繊維の角度 $\theta$ で定義した。（図 1 参照) 標準布強化歯車については $\theta=0^{\circ} \sim 90^{\circ}$, 改良布強 化歯車については $\theta=0^{\circ} \sim 30^{\circ}$ の範聿で実験を行っ た.

2.26 歯の曲け破壊形態 2.2 .5 に示した曲け破壊 試験の際，等方性材料を用いた歯車の破壊挙動とは大 きく異なることが予想される. そこで, 歯の破壊形態 を細かく観察するために接写にて亀裂の進行を調べた.

まず, 標淮布強化歯車の $\theta=0^{\circ} \sim 90^{\circ}$ の繊維配向 の範井において各歯の破壊挙動を観察し, 繊維配向の 違いによる影響, 等方性材料と直交異方性材料を歯車 に用いた場合の破壊挙動の違いを観察する. そして, それぞれ比較考察を行い，各歯車の特性を明らかにす る. また, 積層構成の違う改良布強化歯車の破壊挙動 の観察も行った.

22.7 疲労試験 実際に歯車を使用する場合, 歯 車同士のか子あいにより歯面に繰り返し負荷がかかる. そのため, 本実験で使用した歯車を実機に用いた場合 を想定し, 歯面に一定の繰り返しの片振り荷重を毎秒 2 回の周期で負荷させる疲労試験を各歯車において行 った. 歯車を実際に使用する場合, 疲労試験 $10^{7}$ 回の 耐久性が要求されるので, 測定は最大 $10^{7}$ 回まで行っ た.

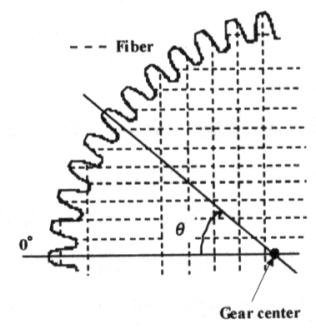

Fig.1 Fiber angle

\section{F R P 歯車材料 の特 性}

3.1 引張強さ 材料の引張試験の結果老図 2 に示 す.この図より標淮布強化材の $\theta=0^{\circ}$ と紙強化材の 引張強さがほぼ同じ $100 \mathrm{MPa}$ 程度であるということ が分かる. また，標準布強化材に関しては $0 \sim 45^{\circ}$ ま でほほ值線的に引張強度が低下している. これは強化 纎維の方向以外の引張では, その強化効果が低下寸る ためと考えられる. 寸なわち直交異方性の傾向が顕著 である. 改良布強化材に関しては, 積層構成の違う標 準布強化材の平均的な引張強さを示しており, 強化繊 維の方向によるばらつき（異方性の傾向）の抑制が見 られる.

32 引張破壊挙動の観察 標準布強化材の $\theta=0$ 〜 $45^{\circ}$ における引張破壊形態を図 3 に示寸。この図よ り $0 \sim 30^{\circ}$ では, 繊維に沿って破壊しており, 破壊強 度は繊維方向の引張応力の影響を大きく受けていると 考えられる. その理由としては引張方向の繊維の強度 がガラス繊維などに比べて低く, マトリックスのフェ ノール樹脂との差が小さいために, 引張に対して垂直 方向 (横繊維) での樹脂と繊維の剥離が支配的である ためと考えられる. $45^{\circ}$ 方向に対しては, 繊維に沿わ ずに引張方向に対して垂直な破壊であった.これは纎 維の強化効率が低いために繊維と樹脂の剥離の前に繊 維が破断したことが原因であると考えられる. また， 改良布強化材においては, $45^{\circ}$ と同様の破壊形態であ った.
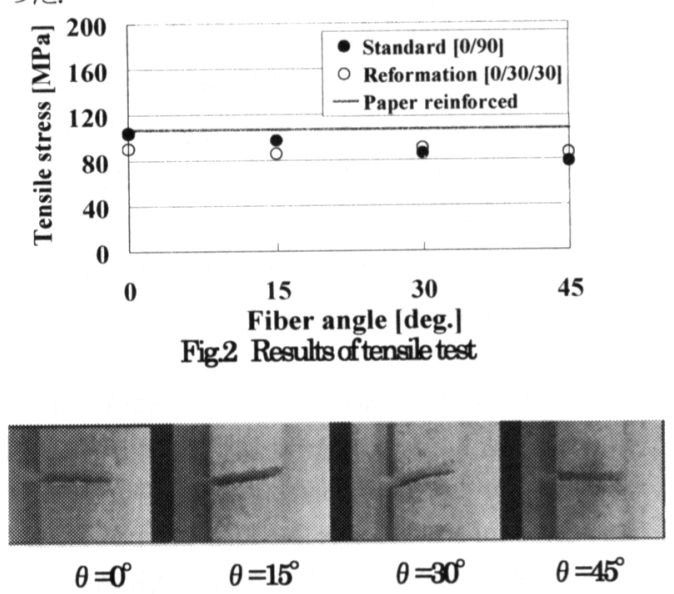

Fig.3 Tensilefracture behavior (Standard material) 3.3 曲げ強さ 歯車の歯元には曲げ応力が発生する. 積層材料では層間の剥離なども考えられるため,曲げ 許容応力も評価しておく必要がある. そこで, 3 点曲 げ試験により標準布強化材の許容曲げ応力を求めた. その結果を図 4 に示寸. 
本報の許容曲げ応力は，引張破壊強度と同様に繊 維配向角が $\theta=0^{\circ} \sim 45^{\circ}$ までほぼ直線的に低下して いる.

3.4 横せん断強さ 横せん断試験の結果を図 5 に 示す. また, 横せん断試験後の状態を図 6 に示寸.

図 6 中で, 紙面に垂直に負荷を加えている図 5 の結 果より, 紙強化材に比べ標準布強化材の横せ九断強 さが高いことがわかる，また図 6 より，紙強化材で は Thickness 方向以外にも（層間はく離などに起因 する）亀裂の進展が見られる。このことより横せん 断試験における紙強化材の強度が低かった原因は積 層材の層間強度の指標之なるへき開強さ（直径 $10 \mathrm{~mm}$ の鋼球で試験片に加圧圧縮し, 試験片がへき 開したときの荷重）が影響していると考えられる.

なぜなら紙強化材に関しては, へき開強度は 4 $6 \mathrm{~N}$ であり，布強化プラスチックのへき開強度である 7 〜11N よりも低い，このことが原因となり紙強化プ ラスチックは布強化プラスチックに比べ早い段階で 層間に亀裂が発生し，その亀裂のために強度が低下 し, 結果としてせん断強度が布強化プラスチックよ りも低くなったと考えられる.

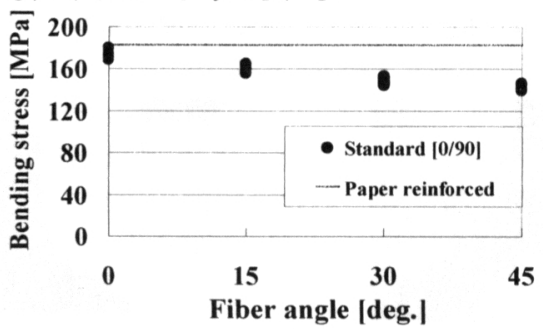

Fig.4result of bendingtest

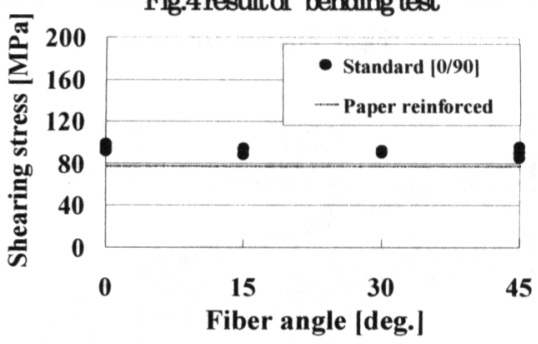

Fig.5 Result of shearing test

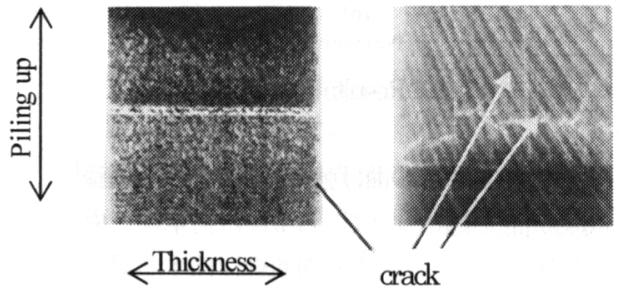

Standard reinforced Paper reinforced Fig.6 Shearing fracture condition
4. F R P 歯 車 の 特 性

4.1 曲け破壊強さ 単位歯幅あたりの荷重と各歯に おける繊維の配向角度との関係を図 7 に示寸. 標準布 強化歯車はモジュールごとに破壊負荷が分かれており， どの歯車においても繊維の強化方向に対しての曲げ破 壊強さの変化は，ほぼ同様の傾向を示している，しか し，モジュールごとに分か冰ていては設計を行う際に 非常に手間がかかってしまうのでモジュールの項をな くして表す必要がある。 また，図7に示されるように 標潐布強化材を用いた場合, 最低值は $\theta=45^{\circ}$ で示し, $\theta=45^{\circ} \sim 90^{\circ}$ での曲げ強度は $\theta=0^{\circ} \sim 45^{\circ}$ での曲 げ強度に比べ高くなった．また改良布強化歯車の積層 構成の違いたよるばらつきの抑制も引張試験結果，3 点曲げ試験結果と同様の傾向を示した.

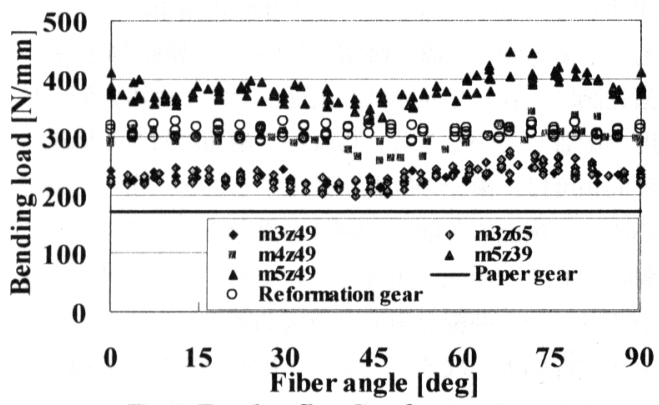

Fig.7 Results ofbending fracture test

図 7 より，紙強化歯車に関しては，標淮布強化歯 車のどの綫維配向角度よりも低い強度を示した．破損 後の歯を観察すると標準布強化歯車は歯元から破断し ているだけであるが，紙強化歯車に関しては歯幅方向 に対して垂直な亀裂による破壊も見られた。このこと より, 紙強化歯車の曲げ破壊試験において強度が低下 した原因については紙基材フェノール樹脂の一き開強 さが影響していると考えられる.つまり, 歯車の歯が stub という特異な形状のため, 曲げ応力のほかにせん 断応力が大きく影響し，歯元での曲け強度で破壊する 標準布強化霜車に比へ，紙強化歯車ではせん断による へき開破壊が先に発生し，強度が急激に低下したもの と考えられる.

また, 2 次元 FEM 解析による直交異方性を考慮し た歯元の応力解析結果を図 8 に示寸，歯先に集中荷重 を加え，歯車リム部を完全固定として計算した．この 結果より, FRP 歯車においては材料異方性により歯 元すみ肉部 (危険断面) だけではなく, 歯元の広い範 囲において応力が高くなっている。このことより FRP 歯車においては, 歯元の広い範囲で破壊起点と なる可能性があることがわかる. 
4.2 曲げ破壊形態 FRP 積層材料を使用した標準布 強化歯車は，歯の曲げ負荷破壊時の亀裂の発生・進展 において積層材料特有の挙動を示す可能性が高い，そ こで, 実際の歯車の歯に対し曲げ破壊試験を行い破壊 形態を観察し，比較考察を行った。

標準布強化歯車の $\theta=0^{\circ}, 45^{\circ}, 51^{\circ}, 75^{\circ}$ と紙強 化歯車，改良布強化歯車の亀裂進展を図 9 に示寸、標 準布強化歯車における破壊形態は，強化繊維に沿った 亀裂と, 沿わない刍裂がある. $\theta=0^{\circ}$ 付近の強度が 低いことに関しては初期亀裂の伝播方向と繊維配向が 一致するためで, 䋊維に沿わない亀裂の場合亀裂の伝 播を強化䋊維が妨げるため強度が増大している。

次に，破断開始位置に関しては，紙強化歯車が金属 歯車と同様に歯元すみ肉部付近（仜険断面）で破断が 開始しているのに対して, 標淮布強化歯車はそれより も少し歯先側の位置で破壊している. 破断開始位置が 歯先側に上昇した原因は，歯面に対する繊維の配向角 度が影響していると考えられる，歯面に対する繊維の 配向角度は，歯元の位置が変化することによって異な るので, 歯面の各部分で岡性が異なる. ここで, 中心 軸に対しての歯面の角度について考えると変曲点 (イ ンボリュート曲線と菌元すみ肉曲線のつなぎ目）で最 も小さな角度となる。 つまり, 中心軸に対する䋊維の 配向角度が $0 \sim 45^{\circ}$ まで変化しても常にこの変曲点で 歯面に対する繊維の配向角度が最も大きくなることが わかる. そのため, 標準布強化歯車の破断開始位置が, 歯元すみ肉部からインボリュート曲線とすみ肉曲線の 接線点一上昇したものと考えられる.

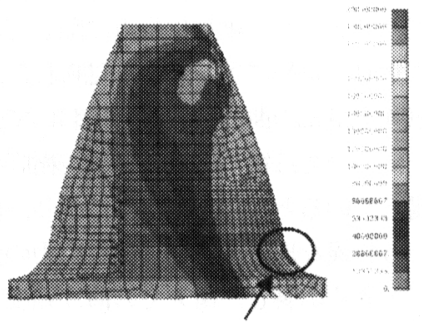

Poor stress concentration

Fig.8 Analytical result

4.3 疲労強度特性 疲労試駼結果も先ほどの曲げ 破壊試験結果と同様に単位柬幅あたりの荷重で表した. その結果をまとめたものを図 10 に示寸. 標淮布強化 歯車に関しては，曲け破壊試験結果同様モジュールご とに破壊負荷が分かれている. 図上り, 標淮布強化歯 車は紙強化歯車上り明らかに疲労限界負荷が高く，同 モジュールで比較すると, 繰り返し数において 100 倍 程度の耐久性を持つことがわかる. 改良布強化歯車に
関しては標準布強化歯車よりも高い疲労強度を示した。 これは繊維が $30^{\circ}$ ごとにあることにより亀裂の進展 を妨げた効果と考えられる.

本実験ではどの歯車においても金属歯車同様度労曲 線はほぼ直線となるが $10^{7}$ 回までで明確な疲労限がな かった. 一般に FRP において疲労限は明確に表現は できないので，107回以上の領域に関しては近似直線 を延長して考えるべきであることもわかる.

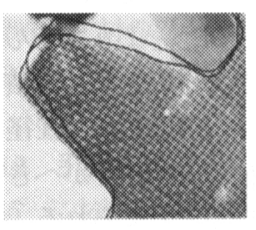

$\theta=0^{\circ}$

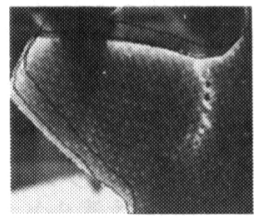

$\theta=51^{\circ}$

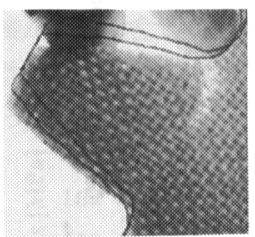

reformation gear

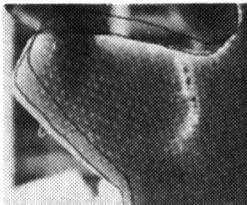

$\theta=45^{\circ}$

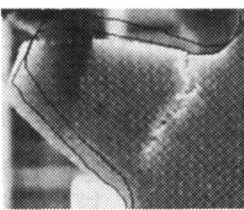

$\theta=75^{\circ}$

\section{Fig.9 Fracture condition}

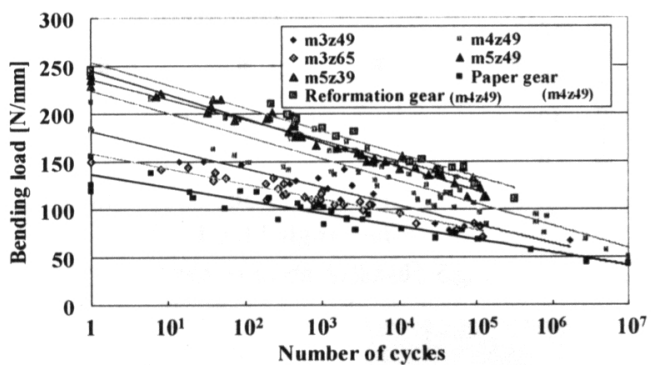

Fig.10 Results of fatigue test

\section{FRP 歯車の曲け強さ設計に関する指針}

5.1 危険断面位置について Lewis は荷重線と歯の中 心線の交点を頂点とし, 寸み肉曲線に接する放物線の 接線を危険断面位置とした ${ }^{12}$ ）。しかしこれは手間が かかるので，実用的には中心線に対して $\phi=30^{\circ}$ 傾い 
た接線の接点を危険断面位置とする $30^{\circ}$ 接線法が多 く採用されている(図 12 中の角度 $\phi$ ) (1)(14).

標淮布強化歯車においては，破断開始位置が歯元 すみ肉部よりかなり菌先側の位置である (図 12 の $\theta$ $=45^{\circ} \sim 75^{\circ}$ 参照) 。これは, $30^{\circ}$ 接線法, 放物線 接線法上りも歯先側の位置であるので, この 2 つの方 法で危険断面の位置を算出することは設計を行ううえ で誤差を大きくする原因となる.したがって，これ以 外の方法を考えた。

まず, 各歯車の破断開始位置を, 歯先からの距離で 測定した. そして, 各モジュールの歯車のデータを全 歯たけで除して位置を整理した. その結果を図 11 に 示す. その結果, 標淮布強化歯車においては歯先から 全歯たけの 8〜9 割のところに破断開始位置が集中し ている.この破断開始位置が集まっている幅を実際の 長さに直すと $1 \mathrm{~mm}$ 程度で繊維径の約 3,4 本分の差 しかないので無視する.この幅を危険断面の位置を示 す接線の傾き角度に直すと $\phi=11 \sim 28^{\circ}$ で, 平均での 角度は約 $15^{\circ}$ 付近である. また, 4.2 節より変曲点付近 で強度が最も低くなることがわかっている，上って， 標淮布強化歯車における危険断面位置の決定法として は $\phi=15^{\circ}$ 接線法が適切であると考えられる.

ただし,この方法は $\theta=0 \sim 45^{\circ}$ の繊維に沿った破 壞の場合のみに適応し， $\theta=45 \sim 90^{\circ}$ の繊維に沿わな い破壊の場合は含まない，また，その範用では強度が 高いので設計を行う上で評価する必要性も少ない，一 方紙強化, 改良布強化歯車について同様に調心゙ると両 者ともに通常の危険断面位置（ $\phi=30^{\circ} ）$ であった.

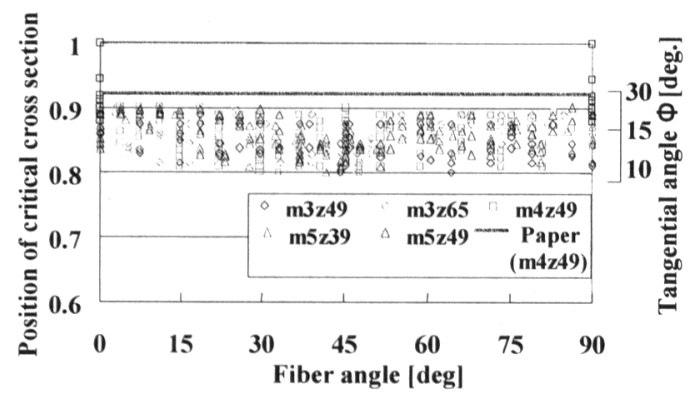

Fig.11 Position of critical cross section

52 歯元応力の式 歯元応力を算出するにあたって, 次の諸点を考慮しなければならない，まず，荷重点の 選定に関しては, 標淮布強化歯車はたわみのため金属 歯車のように厳密なか力合いを期待できないので, 荷

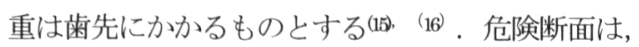
$\phi=15^{\circ}$ 接線法で決定する. 破損に関与する応力は, 曲げ応力 $\sigma_{\mathrm{b}}$ にせん断応力 $\tau$, 圧縮応力 $\sigma_{\mathrm{c}}$ を考慮して
計算を行った. 平歯車の曲け強度計算に必要な諸寸法 は図 12 に示す (わ)。また，等方性材料における $\phi=$ $30^{\circ}$ よりかなり告険断面位置は歯先側にあるので, せ 儿断応力てが大きく影響しているものと考えられる。 そこで危険断面の位置によって変化する歯元応力は歯 形係数を用いずに算出する. そこで本報では，15 接 線で決定された危険断面位置での繊維配向方向 $\theta$ での 相当応力を次式によって求める.

$$
\begin{aligned}
& \sigma_{b}=\frac{6 P_{n} \times \cos \alpha^{\prime} \times h}{b \times m \times S_{F}^{2}} \\
& \sigma_{c}=-\frac{P_{n} \cdot \sin \alpha^{\prime}}{b \cdot S_{F}} \\
& \tau=\frac{P_{n} \cdot \cos \alpha^{\prime}}{b \cdot S_{F}} \\
& \sigma=\frac{\sigma_{b}+\sigma_{c}}{2}-\frac{\sigma_{b}+\sigma_{c}}{2} \cos 2 \theta+\tau \sin 2 \theta \\
& \tau_{15}=\frac{\sigma_{b}+\sigma_{c}}{2} \sin 2 \theta+\tau \cos 2 \theta \\
& \sigma_{15}=\sqrt{(\sigma)^{2}+\left(a \tau_{15}\right)^{2}}
\end{aligned}
$$

ここで， $\sigma 15$ は $15^{\circ}$ 接線法で求めた歯元応力である. a はせん断応力定数で, $\mathrm{a}=2.5$ とする ${ }^{(1)}$ ，標準布強化 歯車の場合強化繊維とマトリックス樹脂が混在してい るため, ひずみゲージを用いて歯元の実灾力を正確に 測定することが困難なので，4.1 節で用いた FEM に より歯元の応力解析を行い, その解析結果を実応力と して, 上記の計算結果と比較を行った. 解析によって 求められた歯元応力 $\sigma_{a}$ を $\sigma_{15}$ と比較するために表 3 に $\sigma_{\mathrm{a}}$ と $\sigma_{15}$ をまとめたものを示す.この 2 つを比較 して, 式 ${ }^{(0)}$ で算出した公称歯元応力 $\sigma 15$ と解析から 求めた歯元実応力 $\sigma$ max より

$$
\beta=\frac{\sigma_{a}}{\sigma_{15}}
$$

を用いて応力集中率を求めると $\beta=1.30$ となった. こ の值は通常の等方性材料を用いた歯車よりかなり低い ものである.この原因は, $\phi=15$ で決定される危険 断面位置が歯元すみ肉曲線より離れているためと考え られる.この応力集中率を用いて $15^{\circ}$ 接線法で算出 した歯元応力を実応力に変換して曲げ破壊試験結果を まとめる. その結果を表 3 に示す。表より両者が良く 一致している様子がわかる. この結果, 歯車の各角度 における歯元の実応力を把握することができる。これ により，この歯車を用いた実験の際にも結果を応力で 整理するという一般的な手法が可能となった. 


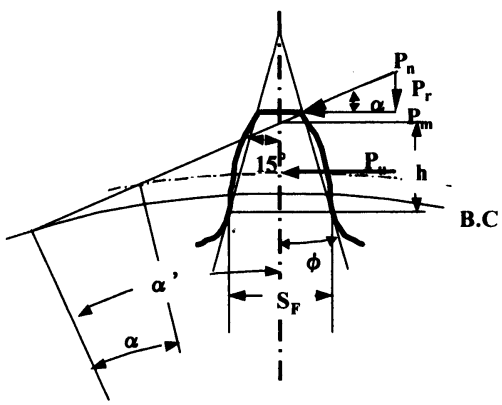

Fig.12 Dimension for stresscalculation

Table.3 Toothrootstrese
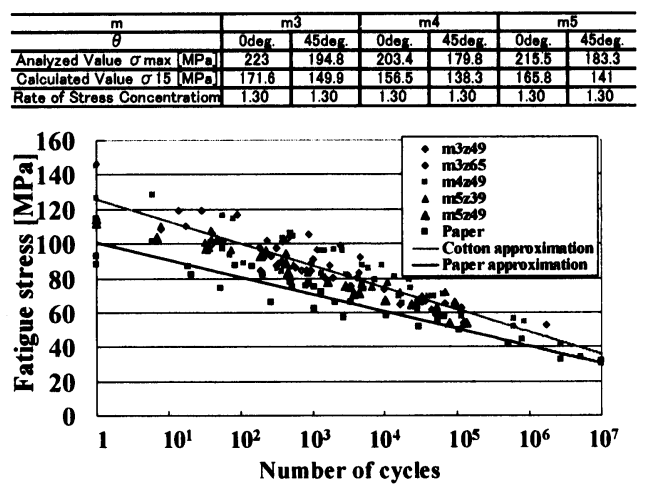

Fig.13 Bending fatigue strength $\left(\theta=45^{\circ}\right)$

5.3 曲げ疲労强度の算定 曲げ破壊試験結果と同様 の応力換算の式を用いて 4.3.節で示した S-N 曲線での 負荷を実応力に変換した. その結果をまとめたものを 図 13 に示す. 許容負荷でまとめた場合と異なり，多 少のばらつきはあるものの曲け破壊試験結果同様モジ ユール, 歯数によらず, ほぼ同じような傾向を示した. すなわち 5.2 節の評価法を用い，これらのデータをモ ジュールに関係なくこの標準布強化歯車の曲げ疲労強 度としてまとめて近似直線を引けることがわかった。 この近似直線を標淮布強化歯車の曲げ疲労強度とする ことによって，布基材フェノール樹脂積層材料で歯車 を設計する上での曲げ疲労強度を容易に算出できるこ とが判明した。

FRP 積層材料を用いた歯車の曲げ試験およひ度労 試験を行い，その結果を本報で提案した. $15^{\circ}$ 接線法 による実歯元応力の算定結果で整理することにより， 曲け強度およひ度労強度を求めておけば， $15^{\circ}$ 接線法 により強度設計が可能となることがわかった。

また，今後は単純引張や曲げ，せん断試験結果と 本分析で求めた歯の曲げおよひ度労強度の関係を詳 細に調べる必要がある.
6. 結 言

電気絶縁材料などに多用される直交積層材料を動 力伝達用歯車に応用するために歯の曲げ疲労強度およ び歯車材料の強度特性を算出し，比較・検討を行った。 その結果，以下のことがわかった。

（1）布基材フェノール樹脂積層材料を用いて製作した 歯車は，破断開始位置が変曲点（インボリュート曲線 と歯元すみ肉曲線の接続部）部となる.

（2）積層材料を歯車に使用した場合，歯車の歯の歯元 強度は層間の剥離強さの指標であるへき開強さも考虑 する必要がある.

（3）布基材フェノール樹脂の FRP 積層材料を用いた 歯車の危険断面の位置を決定する方法は $\phi=15^{\circ}$ 接線 法が適切である．また，危険断面の位置が高いので歯 元すみ肉部の曲率に起因する応力集中係数は小さい.

（4） FRP 積層材料を使用した歯車の歯の歯元強度設 計をする場合，金属歯車のように引張試験の結果だけ でなく，曲け試験，せん断試験の結果も考虑する必要 がある.

\section{文献}

(1)Y.K.Chen, 4 World Congress on Gearing and Power Transmission, (19993), 735

(2)Giuseppe Crippa, 4 World Congress on Gearing and Power'Transmission, (1999), 764

(3)Clifford M. Denny, Testing of Plastic Gears, (1998), 3020

(4)塚本 尚久他, 機論, 63610, O(1997), 2118

(5)塚本 尚久他, 機論, 59568, O(1993), 3866

(6)森脇 一郎他，機論，60-575, O(1994), 2462

(7)小川 正明, 成形加工, Vol.5, No.11, (1993), 821

(8)宮本 宗治・他，日本機械学会第 74 期通常総会講 演会輩演論文集(IV)，2211，(1997)，615

(9)宮入 裕夫, FRP試験, (1989), 91

(10)小田 哲他，機論，45-395，O(1979-7),826

（11)網島 貞男他，材料，21-221，(1971），76

(12)W. Lewis, Investigation of the Strength of Gear Teeth, (1893), Amer. Macht, 16

（13)仙波正荘，歯車，旧第 3 巻，日刊工業新聞社， (1956) , 593

（14)仙波正荘，歯車，新刊第 3 巻，日刊工業新聞社，

(1985)， 84

（15)戸部俊美他，精密機械，34，(1968)，21

（16)寺島健一他，機論，51-468，O(1985-8)，2161

（17)塚本尚久他，機械設計，15-8，（1971），68 